\title{
A Discourse Analysis of Research Texts on Mumpreneurs
}

\author{
Surangi H. A. K. N. S. ${ }^{1}$ and Ranwala R. S. ${ }^{2}$ \\ Department of Commerce and Financial Management, \\ Faculty of Commerce and Management Studies, University of Kelaniya. \\ ${ }^{1}$ surangins @kln.ac.lk, ${ }^{2}$ rsndiniranwala@gmail.com
}

\begin{abstract}
Research investigating female entrepreneurs has developed considerably over the past two decades. However, the muprenurship concept is still a relatively under-researched area, and represents a challenging research field. Departing from a social constructionist understanding of mumpreneurs, this study examines how the entrepreneurial mothers are constructed in research articles. The paper makes use of discourse analysis to examine a selection of empirical research articles from 2000 to 2017 on mumpreneurs in entrepreneurship research in order to convey the key concept, main findings, key contribution, and the methodology. The analysis of the research texts revealed several assumptions and constructs that were taken for granted about mumpreneurs. Main findings based on the discourse analysis reveal five hegemonic statements: Mumpreneurs are not 'proper' entrepreneurs, many women face competing and often contradictory societal expectations when they are combining motherhood and business, entrepreneurship supporting motherhood, new entrepreneurial identity: 'I am not just a housewife, and mumpreneurs' motivations change over and the life course. The practices and the research results are moreover dependent on the particular context in which the articles are produced. This means that their results and assumptions cannot be generalized to other contexts uncritically.
\end{abstract}

Keywords: Female entrepreneurship, Muprenurship, Social Constructionist, Discourse Analysis, Hegemonic Statements

\section{Introduction}

As the number of female entrepreneurs is increasing in most countries, entrepreneurial women are typically still a small proportion of the total population. However, greater

\footnotetext{
${ }^{2}$ https://orcid.org/0000-0002-0577-8845
} 
participation of women in the labour force is a prerequisite to improving the position of women in society and to development of the economy. This chapter also shows that women's contribution to business and to economic growth is almost certainly underestimated, as many women work in the informal sector, and their business activity is not reflected in national statistics, particularly in developing countries such as Sri Lanka.

Historically, it was held that entrepreneurial behaviour was not gender-specific, so the literature considered entrepreneurs as a consistent group, irrespective of gender (Brush, 2006). It was not until the 1980s that researchers who regarded female entrepreneurs as more than simply a small division of entrepreneurship started to gain ground (Moore \& Buttner, 1997). Therefore, researchers began to argue that it was no longer proper to conclude that findings of male entrepreneurs applied equally to women (Loscocco, Monnat, Moore, \& Lauber, 2009). In response to this understanding, separate studies focusing on female entrepreneurs were carried out. Research on female entrepreneurs then began to suggest images of women emulating masculine characteristics and having similar motivations and objectives as their male counterparts (Brush, 2006). The male domination embedded in entrepreneurial discourses was evident in how images of an "iron lady" were used to label female entrepreneurs, whereas traits related with femininity, such as compassion and caring were rarely examined as being associated with entrepreneurship (Bruni, Poggio, \& Gherardi, 2005).

As the number of female entrepreneurs began to increase rapidly (Bygrave, 2006), partially driven by the various development programmes that view women as an economic resource for the market economy, it was argued that a new perspective was required to research female entrepreneurs. In terms of the business type that female entrepreneurs pick, research shows a tendency for female-owned businesses to be small in terms of employment and market share (Carter \& Marlow, 2007) as they are more likely to be working from home using informal sources of finance (Jayawarna, Jones, \& Marlow, 2015). As is evident in a review of research articles published between 1982 and 2000 on female entrepreneurship Ahl (2002) and in 30 years of research on methodological trends in the field of gender and entrepreneurship (Henry, Foss, \& Ahl, 2015), the majority of researchers tend to address the individual profile, psychological characteristics, motivations, educational and occupational experiences, the problems faced, management style and start-up activities such as acquisition of capital. Recent years have witnessed a shift in the research agenda from this early focus to an increasing emphasis on softer issues, including work/family balance and non-financial 
resources such as personal networks (Brush \& Cooper, 2012), entrepreneurial emotion, social entrepreneurship and mumprenurship (Jennings \& Brush, 2013), as well as opportunity recognition, decision-making styles such as bricolage or effectuation, the co-preneur and family-embeddedness perspective of entrepreneurship (De Bruin, Brush, \& Welter, 2007).

Motherhood is culturally defined (Johnston \& Swanson, 2006), and each society has its own customs, beliefs, expectations, values and symbols: the good mother is reinvented as each society defines her anew in its own terms, according to its own traditions (Duberley \& Carrigan, 2013). Social structures such as class and ethnicity substantially influence the ways in which women become mothers, and how they view their responsibilities toward their children (Liamputtong, 2006). Some researchers argue that a good mother is one who is at home, full-time with her children (Johnston \& Swanson, 2006; Duberley \& Carrigan, 2013), whereas others claim that good mothering means that mothers feel they are responsible for caring for their children and training them in domestic work and social development. However, they believe that mothers should not stay at home all day with their children, simply doing everything for them (Gregory \& Milner, 2009; Kodagoda, 2011). In Sri Lankan society, traditional motherhood roles, particularly child-caring and cooking, are viewed as highly-gendered and undeniably an indication of good motherhood, even though women belong to different generations (Kodagoda, 2011). In addition, in the temporary or permanent absence of a male head, mothers have to take over the responsibilities and roles of being the economic provider and protector, as well as continue the roles of nurturing and caregiving (Kodagoda, 2011; Duberley \& Carrigan, 2013). In this setting, departing from a social constructionist understanding of mumpreneurs, this study examines how the mumpreneurs are constructed in research articles.

\section{Methodology}

The methodological approach of this study is inspired by discourse analysis. In the most basic terms, discourse analysis is a research method that involves studying the use of language. Researchers analyse written texts, spoken discursive sign language, and any other means through which communication is achieved. Discourse analysts generally pursue to understand discourse's relations to context, power, and interaction (Ruiz, 2009). Discourse analysis does not offer a tangible answer to problems based on scientific research, but it permits access to the ontological and epistemological enquiry (Carver, 2002). In other words, discourse 
analysis will enable to disclose the hidden motivations behind a text or behind the choice of a particular method of research to interpret that text (Carver, 2002).

In this article, we conferred the concept discourse. The concept forms on a social constructionist perspective where language is identified as constitutive of social reality. Language is designed into discourses, which are ways of thinking about an object that constructs this object. Discourses on mumpreneurs will thus have power implications for mumpreneurs as a group. Discourse Analysis can be applied to any text, that is, to any problem or situation. Since Discourse Analysis is typically an interpretative and deconstructing reading, there are no specific guidelines to follow. Again, the purpose of Discourse Analysis is not to offer definite answers, but to expand the knowledge and make us realize unacknowledged agendas/motivations.

A discourse analysis wishes at questioning power relationships in society, and this specific discourse analysis aims at questioning gender relations as spoken in scientific texts about mumpreneurs. This section explains the particular research texts selected for analysis and then applies the concept of discursive practices to these texts. Researcher takes entrepreneurial mothers, mumpreneurs, female entrepreneurs, gender and entrepreneurship, copreneurand entrepreneurial couples as key words to search the literature researching on the entrepreneurial network which is published in 17 journals (International Journal of Gender and Entrepreneurship; Journal of entrepreneurship theory and practice; Journal of Small Business Management; Strategic Management Journal; International Journal of Small Business; The International Journal of Entrepreneurship and Innovation; Academy of Entrepreneurship, Journal; Journal of Business and Entrepreneurship; Entrepreneurship \& Regional Development; Feminist Economics; Journal of Management Studies; Gender, Work and Organization; International Entrepreneurship Management Journal; Journal of Entrepreneurship; Gender in Management; Journal of Business Venturing; and Journal of Gender \& Society) from 2000 to 2012. All the journals are high impact factor journals of entrepreneurship and gender. The researcher selects the articles based on their relevancy. Subsequently, articles numbered and organized this literature, including authors, date of publication, title, and journal name, contents of research, main findings, key contributions, and research method. 


\section{Analysis}

According to Ahl (2002), a thematic reading guide was created by the authors, with an appropriate coding system developed. The reading guide focused on the particular research topic (mumprenurship) under investigation in the articles, the gender perspective employed. It was decided early on in the process to use a manual coding system. Analysis has three stages: the coding of text line-by-line, the development of "descriptive themes", and the generation of "analytical themes". While the development of descriptive themes remains close to the primary studies, the analytical themes denote a stage of interpretation whereby the critics 'go beyond' the primary studies and generate new interpretive constructs and explanations. Later, the use of NVivo 10 facilitates this method of synthesis; detailed guidance is given on how this can be achieved.

The next section presents the findings from each of the 17 year review periods.

\section{Findings - Hegemonic Statements}

\section{Mumpreneurs are not 'proper' entrepreneurs- family first, business second}

One of the tendencies within research on female entrepreneurs is to focus on how expectations of women being responsible for family matters affect those women who engage in entrepreneurship, as is evident in reviews of studies on female entrepreneurs (Ahl, 2006). Therefore, as a growing body of research conducted on female entrepreneurs focuses on the assumption that female entrepreneurs" "primary responsibility is the family" (Bruni, Poggio, \& Gherardi, 2005), the importance of gender roles within conceptualizations of entrepreneurship becomes apparent. Indeed, society motivates women to be producers and reproducers, leading women to deal with the task of managing familial responsibilities with work commitments (Woldie \& Adersua, 2004). An understanding of the difficulties inherent in women being perceived as business owners and mothers or housewives is evident in how the balancing of family and working life is one of the most pressing issues facing every society (Crompton, Lewis, \& Lyonette, 2007).

\section{Many women face competing and often contradictory societal expectations when they are combining motherhood and business}

Women often face contradictory societal expectations with regard to career development and motherhood (Duberley \& Carrigan, 2013). Both "at home" and employed/business mothers 
are affected by this ideology (Johnston \& Swanson, 2006); they are expected to sacrifice their own needs for those of their children and to commit their time to the care of their children and their leisure activities (Johnston \& Swanson, 2006). A common factor among research articles was that mumpreneurs all wanted to be available to look after their children and a majority described stressful times trying to combine their business with motherhood.

Martin (2001) finds that the main obstacle for female owner-managers when identifying with existing business associations, clubs or networks, is lack of time. Blisson and Rana (2001) find that it is difficult for women to attend meetings because of their family commitments. Sonfield and Lussier (2009) reveal that women have been found to be more dependent and have a greater concern for others, particularly their families, whereas men tend to be more independent. Blisson and Rana (2001) found that the main barriers to existing networks cited by Asian women were attributable to their gender, cultural background and their consequent lack of confidence. To be precise, the difficulties in attempting to network with others in business groups were related to their domestic responsibilities and culture not permitting them to run their business in the same way that men were able to (Blisson \& Rana, 2001).

\section{Entrepreneurship supporting motherhood}

Many women need flexibility between their work roles and their roles as mothers, and this is a factor in their motivation for entrepreneurship (Kirkwood, 2012). Interestingly, mothers journey to entrepreneurship were encouraged by motherhood, but it also serves as a supplement to it. Furthermore, it is apparent that she chose entrepreneurship more out of necessity than desire. Similar results have been found in the UK (Vadnjal, Tajnikar, \& Vadnjal, 2009), as studies reveal that the amount of time a woman devotes to her business is linked to her life-stage, which explains why some women do not want to further develop their businesses. Female entrepreneurs choose entrepreneurship because of family issues and do not need to grow the business, as their existence does not depend on it (Vadnjal, Tajnikar, \& Vadnjal, 2009).

Duberley and Carrigan (2013) who suggests that women are using entrepreneurship as a path to try to sustain a certain lifestyle and identity which lets them meet their desire to maintain an entrepreneurial career with their desire to fulfil a particular version of being a good mother. The much extant research considers gender roles as constraints rather than enable factor for female entrepreneurship as such roles place responsibility for household responsibilities and childrearing on women (Welter, 2004). 


\section{Entrepreneurial identity: 'I am not just a housewife"}

Many comparative gender studies specifically find that women are more influenced than men in areas such as family responsibilities (Klyver, 2007; Blisson \& Rana, 2001), domestic commitments and child-rearing. This is strongly supported by many research articles.

They limit their business activities in order to be able to be at home with their children; however, they are less available to their children compared to "full-time, stay at home" mothers (Duberley \& Carrigan, 2013). Therefore, they have rejected the identity of a fulltime "stay at home" mother and created a business as a means of developing a new career identity which combines motherhood and work. Mumpreneurs are less available to her children than they might be as "stay at home" mothers (Surangi, 2017). Instead of viewing gender role identity one-sidedly as a constraint, some researchers arguments advanced are employed to develop a more balanced perspective on motherhood as being an enabling factor in female entrepreneurship (Leung, 2011).

\section{Running home-based business}

It is undeniably advantageous if entrepreneurs do business in the same place as where they have been living all their life or for a considerable time, for example, places where they have been raised since childhood, completed their education etc. The associated benefit is that the individual in question already has a pre-existing social network established, one which an entrepreneur is able to take advantage of. It was found that, for the majority of articles, the family home was the location for their business activity; one part for family, one part for tourists and one part for a restaurant as well. It is much easier setting up a business in one's home place, as no time is wasted in developing a network sufficiently helpful to support the entrepreneurs' business on a daily basis (Surangi, 2017). Furthermore, running home-based businesses and being mothers enabled them to work flexibly; they can meet their domestic needs, including child care, easily. On the one hand, these so-called "mumpreneur" businesses, organized to work around the routines of child care, enable the women to be available for domestic work most of the time (Surangi, 2017).

On the other hand, the location of their business is their home had become a problem in their homes, and pressure had arisen because of their husbands and other family members. The family home is a place where these women's husbands and other family members expected them to conform to their identities solely as mothers and wives. In addition, running home- 
based businesses restricts the woman's business identity (Surangi, 2017), and this case does identify some of the potential disadvantages of growing business within a family space (Surangi, 2017). These findings are consistent with Ekinsmyth (2013), who found tensions involved in home-based work in the UK, specifically with regards to isolation, workaholism, space restrictions and a negative influence on home-space and family lives (Ekinsmyth, 2013). Moreover, some researchers revealed the tensions involved in home-based businesses, particularly with regards to isolation (Mason, Carter \& Tagg, 2011), space limitations and a negative impact on home-space and family lives (Surangi, 2017).

\section{Mumpreneurs' motivations change over the life course}

Traditionally, women with children delayed until the children were past secondary school before becoming an entrepreneur (Kirkwood, 2012; Duberley \& Carrigan, 2013). However, women with elder children are now choosing entrepreneurship because it gives a chance to overcome childcare problems (Kirkwood, 2012). Further, it reveals that it is essential to recognize the temporal embeddedness of women business owners' current identity constructions and their situation is dynamic and evolving, and priorities may change as their children get older.

\section{Conclusion}

This article has reviewed the key literature published on female entrepreneurship and has found that women are generally under-represented in business, making female entrepreneurship an important, unexploited economic potential. Muprenurship concept is still a relatively under-researched area and represents a challenging research field. The findings from this study make a number of contributions to the current literature. More specifically the findings increase awareness of the entrepreneurial mother, the norms and values associated with their social life and business life based on the cultural context. This study offers a rich insight into the women identities and experiences of mumpreneurs in research texts as it makes a considerable contribution to the specific body of knowledge on the area of entrepreneurship and gender of combining mothering with business (Duberley \& Carrigan, 2013; Leung, 2011; Jean \& Forbes, 2012). Because this article highlights the social and temporal embeddedness of entrepreneurship and the ways in which the mumpreneur identity is developed through the active engagement with coexisting, competing and sometimes contradictory discourses. The study adds depth to the questioning of the split between family 
and entrepreneurship that is common in entrepreneurship research (Duberley \& Carrigan, 2013; Leung, 2011; Jean \& Forbes, 2012).

As identified in this chapter, mumprenurship area yet to be developed in methodological, theoretical and conceptual terms. The concept of mumpreneurs has been discussed by researchers from different academic disciplines, particularly those of Business, Economics and Sociology. However, a general conceptual framework for investigating mumprenurs is still absent.

\section{References}

Ahl, H. (2006). Why research on women entrepreneurs needs new directions. Entrepreneurship theory and practice, 30(5), 595-621. https://doi.org/10.1111/j.1540$\underline{6520.2006 .00138 . x}$

Ahl, H. J. (2002). The making of the female entrepreneur: A discourse analysis of research texts on women's entrepreneurship. PhD. Jonkoping International Business School.

Blisson, D., \& Rana, B. K. (2001). The role of entrepreneurial networks: The influence of gender and ethnicity in British SMEs. In 46th ICSB World Conference. Taipei, Taiwan.

Bruni, A., Poggio, B., \& Gherardi, S. (2005). Gender and entrepreneurship: an ethnographic approach. New York: Routledge. https://doi.org/10.4324/9780203698891

Brush, C. G. (2006). Women entrepreneurs: A research overview. The Oxford handbook of entrepreneurship.

Brush, C. G., \& Cooper, S. Y. (2012). Female entrepreneurship and economic development: An international perspective. Entrepreneurship \& Regional Development, 24(1-2), 16. https://doi.org/10.1080/08985626.2012.637340

Bygrave, W. D. (2006). The entrepreneurship paradigm (I) revisited', in H. Neergaard and J. ParmUlhøi (Eds.). In Handbook of qualitative research methods in entrepreneurship (pp. 17-48). Cheltenham: Edward Elgar Publishing. 
Carter, S., \& Marlow, S. (2007). Female entrepreneurship: theoretical perspectives and empirical evidence. In N. Carter, C. Henry, B. O. Cinneide, \& K. Johnston, Female entrepreneurship: implications for education, training and policy. London: Routledge.

Carver, T. (2002). Discourse analysis and the linguistic turn. European Political Science Autumn, 50-53. https://doi.org/10.1057/eps.2002.46

Crompton, R., Lewis, S., \& Lyonette, C. (2007). Introduction: the unravelling of the 'male breadwinner'model — and some of its consequences. In Women, men, work and family in Europe. https://doi.org/10.1057/9780230800830_1

De Bruin, A., Brush, C. G., \& Welter, F. (2007). Advancing a framework for coherent research on women's entrepreneurship. Entrepreneurship theory and practice, 31(3), 323-339. https://doi.org/10.1111/j.1540-6520.2007.00176.x

Duberley, J., \& Carrigan, M. (2013). The career identities of 'mumpreneurs': Women's experiences of combining enterprise and motherhood. International Small Business Journal, 31(6), 629-651.https://doi.org/10.1177/0266242611435182

Ekinsmyth, C. (2013). Managing the business of everyday life: the roles of space and place in "mumpreneurship". International Journal of Entrepreneurial Behaviour \& Research, 19(5), 525-546. https://doi.org/10.1108/IJEBR-10-2011-0139

Fiona, B. (2017), "'A beautiful mess': Reciprocity and positionality in gender and tourism research.'", Journal of Hospitality and Tourism Management, Special Issue: A critical lens on hospitality and tourism work, 33, 126-133. https://doi.org/10.1016/j.jhtm.2017.09.009

Gregory, A., \& Milner, S. (2009). Work-life balance: A matter of choice? Gender, Work \& Organization, 16(1), 1-13. https://doi.org/10.1111/j.1468-0432.2008.00429.x

Henry, C., Foss, L., \& Ahl, H. (2015). Gender and entrepreneurship research: A review of methodological approaches. International Small Business Journal, 1 -25.

Jayawarna, D., Jones, O., \& Marlow, S. (2015). The influence of gender upon social networks and bootstrapping behaviour. Scandinavian Journal of Management, 31, 316-329. https://doi.org/10.1016/j.scaman.2015.06.002 
Jean, M., \& Forbes, C. S. (2012). An Exploration of the Motivations and Expectation Gaps of Mompreneurs. Journal of Business Diversity, 12(2), 112-132.

Jennings, J. E., \& Brush, C. G. (2013). Research on women entrepreneurs: challenges to (and from) the broader entrepreneurship literature? Academy of Management Annals, 7(1), 663-715. https://doi.org/10.5465/19416520.2013.782190

Johnston, D., \& Swanson, D. (2006). Constructing the 'good mother': The experience of mothering ideologies by work status. Sex Roles, 54(7-8), 509-519. https://doi.org/10.1007/s11199-006-9021-3

Kodagoda, D. T. (2011). Gendered moral rationalities in combining motherhood and employment a case study of Sri Lanka. UK: PhD. Department of Social Sciences and Humanities, University of Bradford.

Leung, A. (2011). Motherhood and entrepreneurship: gender role identity as a resource. International Journal of Gender and Entrepreneurship, 3(3), 254-264. https://doi.org/10.1108/17566261111169331

Liamputtong, P. (2006). Motherhood and "moral career": Discourses of good motherhood among Southeast Asian immigrant women in Australia. Qualitative sociology, 29(1), 25-53. https://doi.org/10.1007/s11133-005-9006-5

Loscocco, K., Monnat, S. M., Moore, G., \& Lauber, K. B. (2009). Enterprising women: A comparison of women's and men's small business networks. Gender \& society, 23(3), 388-411. https://doi.org/10.1177/0891243209336741

Kirkwood, J.J. (2016) "How women and men business owners perceive success", International Journal of Entrepreneurial Behavior \& Research, Vol. 22 Issue: 5, pp.594-615.

Moore, D. P., \& Buttner, E. H. (1997). Women entrepreneurs: Moving beyond the glass ceiling. Sage Publications, Inc.

Ruiz, J. R. (2009). Sociological Discourse Analysis: Methods and Logic. Qualitative Social Research, 10(2), 33-47. 
Sonfield, M. C., \& Lussier, R. N. (2009). Family-member and non-family-member managers in family businesses. Journal of Small Business and Enterprise Development, 16(2), 196-209. https://doi.org/10.1108/14626000910956010

Surangi, H. A. (2017). The Role of Female Entrepreneurs' Networks: A Study Based on Small Businesses in the Tourism Sector in Sri Lanka. United Kingdom: PhD Thesis, University of Lincoln.

Surangi, H.A.K.N.S. (2018) .What influences the networking behaviours of female entrepreneurs? A case for the small business tourism sector in Sri Lanka, International Journal of Gender and Entrepreneurship, https://doi.org/10.1108/IJGE08-2017-0049https://doi.org/10.1108/IJGE-08-2017-0049

Swail, J. and Marlow, S. (2017) 'Embrace the masculine; attenuate the feminine'- gender, identity work and entrepreneurial legitimation in the nascent context', Entrepreneurship and Regional Development, pp 1-44.

Vadnjal, M., Tajnikar, M., \& Vadnjal, J. (2009). Female start-ups in the light of crisis: emotional versus traditional support. 8th International Conference on Challenges of Europe (pp. 243-259). Croatia: Split-Bol.

Varlander, S, Klyver, K \& Sölvell, I (2017), 'Culture as Motivation and Justification in Entrepreneurship: A Dual Cultural Framework' Paper presented at, Copenhagen, Denmark, 06/07/2017 - 08/07/2017. https://doi.org/10.5465/ambpp.2017.14164abstract

Woldie, A., \& Adersua, A. (2004). Female entrepreneurs in a transitional economy: Businesswomen in Nigeria. International Journal of Social Economics, 31(1/2), 7893. https://doi.org/10.1108/03068290410515439 